\title{
Analisa Foto Mengenai Maskulinitas Kandidat Presiden RI Tahun 2014
}

\author{
Nathaniel Antonio Parulian ${ }^{1}$ \\ ${ }^{1}$ Department of Communication Science, Universitas Pembangunan Jaya \\ South Tangerang, Banten 15413, Indonesia \\ nathaniel.antonio@upj.ac.id
}

Received 13 May 2020, Revised 30 October 2020, Accepted 2 November 2020

\begin{abstract}
Every journalistic photo published via mass media thru an event coverage possessed an opportunity to create understanding of hidden meanings that can create an emotional response in a form of imagination to published journalistic photos. One form of imagination is a visual image of journalistic photos about masculinity for 2014 Indonesian presidential candidates, which were published by the mass media. In order to clarify a masculinity characteristic description, there is a need for research to recognize masculinity images that can be traced with the concept of gender, patriarchy culture and stereotype which are attached to each 2014 Presidential candidates personality. This research is using a paradigm subjective-interpretive, with qualitative content analysis method and semiotics of Roland Barthes. Primary data of the research is visual images of journalistic photos and interviews. Secondary data of the research is literature studies. Interviews are accomplished by interviewing journalistic photographers and social psychologists. The result showed that masculinity of the 2014 Indonesian presidential candidates in daily national news papers showed a similarity that can be linked together into different categories and are the differences in personality characteristics of each presidential candidate. This is because of differences in public roles about masculinity images especially in patriarchy culture.
\end{abstract}

Keywords: Photo Journalism, Symbolic Interaction, Masculinity.

\begin{abstract}
Abstrak - Setiap foto-foto jurnalistik yang dimuat di media massa melalui liputan sebuah peristiwa memiliki peluang untuk menciptakan penafsiran terhadap makna-makna yang tersembunyi yang dapat menimbulkan respons emosional berupa imajinasi terhadap foto-foto jurnalistik yang di publikasikan. Salah satu bentuk imajinasi itu adalah dari tampilan visual foto-foto jurnalistik mengenai sifat-sifat maskulinitas kandidat presiden RI tahun 2014 yang dimuat dimedia massa. Agar dapat menjelaskan deskripsi akan sifat-sifat maskulinitas yang melekat diperlukan penelitian untuk mengetahui gambaran maskulinitas yang dikaitkan dengan konsep gender, budaya patriarki dan stereotype yang tampak dan melekat pada masing-masing pribadi kandidat presiden pemilihan umum tahun 2014. Penelitian ini menggunakan paradigma subjektif-interpretif, metode penelitian analisis isi-kualitatif dengan analisa semiotika Roland Barthes. Pengumpulan data penelitian dilakukan dengan data primer berupa tampilan visual foto-foto jurnalistik dan wawancara, serta data sekunder berupa studi literatur. Wawancara dilakukan dengan fotografer jurnalistik dan psikolog sosial. Hasil penelitian menunjukkan, maskulinitas kandidat presiden RI tahun 2014 di surat kabar harian nasional terdapat persamaan yang dapat digabungkan menjadi beberapa kategori dan juga perbedaan akan sifat yang melekat di dalam diri masing-masing kandidat presiden. Hal tersebut disebabkan oleh adanya perbedaan peran dalam masyarakat tentang gambaran maskulinitas terutama dalam kebudayaan patriarki.
\end{abstract}

Kata Kunci: Foto Jurnalistik, Interaksi Simbolik, Maskulinitas.

\section{PENDAHULUAN}

Hadirnya foto dalam bidang jurnalistik sebagai medium untuk menyampaikan pesan dan informasi, sudah diakui eksistensinya sejak ratusan tahun yang lalu, terbukti dengan pernyataan Muhtadi (1999:100101) yang menjelaskan tentang sejarah munculnya foto jurnalistik sebagai media foto pertama kali ditemukan oleh Joseph Nicephone Niepce, dimana ia memulai pekerjaannya pada tahun 1813 dengan menggunakan alat bantu semacam "kamera" yang disebut camera obscura. Sementara itu, penggunaan foto jurnalistik dalam koran dan majalah mulai berkembang pada tahun 1930-an. Perkembangannya sangat cepat sehingga pada gilirannya teknologi foto dapat mendorong perkembangan media jurnalistik. Jadi, foto-foto jurnalistik yang kita kenal saat ini, merupakan akibat perkembangan dan kemajuan yang terjadi pada era sebelumnya.

Akibat perkembangan dan kemajuan yang terjadi terhadap foto jurnalistik sejak ratusan tahun yang lalu, menyebabkan foto jurnalistik dianggap memiliki pergeseran fungsi sehingga kini foto jurnalistik menjadi kunci dalam proses komunikasi untuk mendeskripsikan suatu pesan tertentu yang secara 
eksplisit tidak tertuang dalam proses komunikasi verbal maupun tulisan. Dalam Muhtadi (1999:100101) disampaikan, foto jurnalistik kemudian tumbuh menjadi suatu konsep dalam sistem komunikasi yang sekarang disebut komunikasi foto (photographic communication) bahkan komunikasi foto kini telah menempati kunci model dalam proses komunikasi massa. Foto dan gambar dapat mendeskripsikan suatu pesan yang tidak secara eksplisit tertuang dalam komunikasi verbal baik lisan maupun tulisan. Artinya, kedudukan foto dalam ilmu jurnalistik di anggap lebih tinggi kedudukannya dalam mendeskripsikan suatu pesan, karena dapat memberikan penjelasan yang lebih terperinci dari pemberitaan dalam bentuk verbal.

Sebagai medium yang dianggap lebih tinggi kedudukannya dalam menyampaikan suatu pesan, menyebabkan dalam setiap pemberitaan visual berupa foto jurnalistik dapat membentuk opini tertentu. Secara teoritis Sugiarto (2005:19-22) mengemukakan pendapatnya mengenai bahasa gambar yang langsung dapat memberi dampak berupa persepsi mengenai kejadian tertentu. Singkat kata, gambar menimbulkan respons emosional lebih cepat daripada tulisan. Jadi, kehadiran foto jurnalistik akan memiliki dampak secara langsung atas pesan visual yang tampak karena mampu menimbulkan respons emosional yaitu berupa imajinasi khalayak dalam suatu peristiwa yang terjadi di dalamnya.

Dari asumsi peneliti dan seluruh ahli dapat disimpulkan bahwa setiap foto-foto jurnalistik yang dimuat di media massa melalui liputan sebuah peristiwa akan memiliki peluang dan kemungkinan untuk menciptakan penafsiran khalayak terhadap makna-makna tersembunyi yang dapat menimbulkan respons emosional berupa imajinasi khalayak termasuk penafsiran sifat-sifat maskulinitas yang dikaitkan dengan konsep gender, budaya patriarki dan stereotype yang tampak dan melekat pada sosok kandidat presiden RI atas peristiwa yang terjadi dan menjadi sebuah isu nasional dalam pemberitaan melalui tampilan visual foto-foto jurnalistik di media massa yaitu pada masa-masa menuju pemilihan umum presiden RI tahun 2014 yang lalu.

Seperti yang kita ketahui bersama, dalam setiap pemberitaan melalui tampilan visual berupa foto yang dimuat di media massa pada umumnya sifat-sifat maskulinitas di kaitkan dengan sosok pria tampan, mapan dan jantan secara fisik. Namun, sejatinya sifatsifat maskulinitas lahir tidak serta merta hanya karena penilaian secara fisik semata, tetapi lahir karena beberapa faktor diantaranya konsep gender, budaya patriarki dan stereotype. Dalam Moore (dikutip dari Abdullah, 2003:266) dijelaskan bahwa gender diartikan sebagai konstruksi sosial kultural yang membedakan karakteristik maskulin dan feminin. Gender berbeda dengan seks atau jenis kelamin lakilaki dan perempuan yang bersifat biologis. Walaupun jenis kelamin laki-laki sering berkaitan erat dengan gender maskulin dan jenis kelamin perempuan berhubungan dengan gender feminin, kaitan antara jenis kelamin dengan gender bukanlah merupakan korelasi absolut (Moose dikutip dari Abdullah, 2003: 266). Artinya, setiap individu pria dan wanita tidak selamanya memiliki sifat-sifat yang di golongkan kedalam kelompok maskulin dan feminin, melainkan tergantung penilaian atribut sosial budaya yang melekat dan sudah disepakati bersama oleh masyarakat setempat dan memberi dampak bagi kehidupan sosial individu tersebut.

Aspek sosial dan budaya yang dikemukakan sebelumnya, juga memberi dampak terhadap pandangan maskulinitas di Indonesia, dimana Indonesia merupakan salah satu negara yang menganut suatu budaya yang memposisikan laki-laki diatas perempuan berdasarkan stratifikasi sosial. Konsep budaya yang demikian, disebut dengan budaya patriarki. Dalam Nimrah (2015:175) dijelaskan, ciri-ciri negara yang menganut budaya patriarki yaitu kedudukan laki-laki yang selalu mendominasi perempuan. Perempuan selalu saja dipandang orang kedua setelah laki-laki, karena lakilakilah yang selalu mengambil keputusan, baik dalam keluarga maupun ditempat kerja. Apa yang dijelaskan diatas memiliki arti, bahwa setiap pribadi atau individu yang hidup dalam satu budaya patriarki yang dianut negara Indonesia, maka dalam aspek kehidupan kerja di negara Indonesia secara keseluruhan di atur dan di dominasi oleh laki-laki.

Dominasi laki-laki dalam budaya patriarki disebabkan oleh penilaian terhadap individu laki-laki yang dianggap memiliki kekuatan yang lebih, agresivitas yang tinggi, serta dapat berpikir dan bertindak secara rasional. Dalam Darwin (1999:3) ia menegaskan pernyataan tersebut terjadi karena menyangkut stereotype maskulinitas dan feminitas, dari berbagai aspek karakteristik individu seperti karakter atau kepribadian, perilaku peranan, okupasi, penampakan fisik, ataupun orientasi seksual, dimana laki-laki diciri oleh watak yang terbuka, kasar, agresif, dan rasional, sementara perempuan bercirikan tertutup, halus, afektif dan emosional. Dalam hal okupasi pekerjaan yang mengandalkan kekuatan dan keberanian disebut sebagai pekerjaan yang maskulin sementara pekerjaan yang memerlukan kehalusan, ketelitian, dan perasaan dinamakan pekerjaan feminin. Stereotype inilah yang pada gilirannya menciptakan hubungan yang bias antara laki-laki dan perempuan, dimana hegemoni laki-laki atas perempuan dianggap sesuatu yang kodrati. Jadi, apa yang dikemukakan diatas, menjadi sebuah kebiasaan di masyarakat yang menganut konsep budaya patriarki dalam memberikan penilaian terhadap lakilaki dan perempuan, dengan adanya stereotype yang kuat kepada laki-laki terhadap penilaian akan kekuatan dan keberanian yang dimiliki, maka akan memberi dampak terhadap pemaknaan foto-foto jurnalistik yang dipublikasikan di media massa.

Pada perkembangannya sifat-sifat maskulinitas tidak hanya dapat dikaitkan dengan konsep gender dan budaya patriarki saja, melainkan juga dapat 
diukur melalui sifat-sifat yang yang disepakati oleh masyarakat dalam ruang lingkup tertentu. Pernyataan tersebut dibuktikan sesuai dengan pernyataan yang dikemukakan oleh Lampe (2014:362) dimana maskulinitas terjadi melalui proses sosialisasi, penguatan, konstruksi sosial, kultural, keagamaan dan kekuasaan negara yang menimbulkan efek stereotype, yang menurut Nasdian (2015:298) yaitu dengan adanya pemberian cap atau identitas yang merefleksikan kesan dan keyakinan tentang tingkah laku yang tepat bagi laki-laki atau perempuan untuk membenarkan suatu tindakan.

Rokhmansyah (2016:11) merumuskan tentang sifat-sifat stereotype laki-laki yang diakui dan menjadi citra dalam masyarakat yang menganut budaya patriarki dari aspek kondisi fisik antara lain: atletis, besar dan tegap, berotot, tinggi, bersuara tinggi, dan kuat, dari aspek sifat antara lain: selalu ingin bersaing, kurang sensitif, mendominiasi, petualang, agresif, dan berani, dari aspek pemikiran antara lain: analitis, hebat dalam urusan angka, abstrak (tidak artistik), pintar dalam memecahkan masalah secara logik, tidak berdasarkan intuisi dan pintar memberi alasan.

Merujuk pada penggambaran, penjelasan dan pendapat diatas maka maskulinitas tidak hanya dapat dimaknai dari atribut yang nampak, melainkan dapat dimaknai sebagai suatu konsep yang lahir dari kesepakatan masyarakat dan dikaitkan dengan konsep gender, budaya patriarki dan stereotype dalam ruang lingkup tertentu dan hal tersebut menjadi pendorong dan pemicu bagi peneliti untuk menjawab rasa keingintahuan yang besar mengenai pemaknaan maskulinitas yang tampak dan melekat melalui tampilan visual foto-foto jurnalistik kandidat presiden RI tahun 2014 yang dimuat diharian surat kabar nasional, dengan demikian akan menciptakan peluang bagi peneliti untuk memberikan penafsiran makna foto-foto jurnalistik terhadap sosok kandidat presiden RI tahun 2014 yaitu tentang tampilan visual aktivitas dan peran masing-masing kandidat presiden selama kampanye pemilihan umum presiden RI tahun 2014. Aktivitas dan peran kandidat presiden menjadi sangat menarik untuk ditampilkan dalam satu liputan, karena mampu menampilkan sesuatu yang dilekatkan dan diasosiasikan kepada masing-masing kandidat presiden.

\section{KAJIAN LITERATUR}

\section{Teori Interaksi Simbolik}

Teori interaksi simbolik adalah sebuah teori yang sangat mengagumi kemampuan manusia untuk menggunakan simbol dalam bertindak berdasarkan makna simbolik yang muncul didalam sebuah situasi tertentu. Tiga asumsi interaksi simbolik telah dirumuskan oleh Herbert Blumer pada tahun 1969 yang dikutip dari West (2008:99-100), terdiri dari: manusia bertindak terhadap manusia lainnya berdasarkan makna yang diberikan orang lain kepada mereka, makna diciptakan dalam interaksi antar manusia, serta makna dimodifikasi melalui proses interpretatif. Prinsip utama dari interaksionisme simbolis menurut Rivers (2004:28-29) terdiri dari orang-orang yang sedang bersama-sama dalam sebuah aksi sosial manusia yang bersifat interaktif antar individu.

Lebih lanjut Rivers (2004:28) menegaskan, bahwa manusia kerap berkomunikasi dengan menggunakan simbol dan mampu bereaksi tidak hanya terhadap lingkungan fisiknya, namun juga pada simbol-simbol yang dibuatnya sendiri. Senada dengan hal tersebut Boulding (dikutip dari Rivers, 2004:28) berpendapat tentang sifat keunikan yang dimiliki manusia, dimana manusia tidak hanya memiliki kemampuan dalam penalaran, namun kecakapannya dalam memahami dunia simbolik baik yang bersifat artistik, mistis maupun religius.

\section{Kerangka Konseptual \\ Foto Jurnalistik}

Foto jurnalistik sebagai sajian gambar atau foto yang dapat berdiri sendiri sebagai visualisasi suatu peristiwa. Foto jurnalistik dapat melekat pada suatu berita sebagai pelengkap dan penguat pesan yang disampaikan dalam berita, sesuai dengan apa yang dikemukakan oleh Yunus (2010:91), foto jurnalistik pada dasarnya sama dengan foto dokumentasi pada umumnya. Hanya saja, foto jurnalistik memiliki kelebihan karena dipublikasikan pada media massa, dengan demikian foto jurnalistik harus memiliki daya tarik yang tinggi. Kegiatan foto jurnalistik perlu menekankan pada upaya pencarian, pengumpulan, pengolahan, dan penyebaran foto yang mengandung nilai berita melalui media massa. Foto jurnalistik harus memiliki kemampuan bercerita melalui gambar. Foto jurnalistik yang baik, adalah karya foto yang mampu menyajikan cerita secara ekspisit dan implisit, tanpa harus menjelaskan isi foto yang disajikan.

\section{Kriteria Teknis Pembentuk Tanda Dalam Foto Jurnalistik}

Teknik fotografi digunakan untuk memberi kesan tertentu dalam pembuatan film, karena pada hakekatnya film dan foto adalah sama-sama menggunakan visual, maka teknik pengambilan gambar di dalam film juga dapat digunakan dalam fotografi. Adapun kriteria-kriteria pembentuk tanda secara teknis dalam teknik pengambilan gambar foto jurnalistik dapat dilihat seperti yang dikemukakan oleh Irsyad (2005:31-41) yang terlampir dibawah ini:

Sudut Pandang: sudut pandang bird's eye view merupakan sudut pandang yang paling menyesatkan, karena melakukan pemotretan tepat diatas subjek. Sudut pandang ini subjek tampak tidak dikenali atau akan tampil sebagai subjek yang tidak penting atau tidak berarti. Sudut pandang high angle, dapat memberi kesan mengurangi pentingnya subjek atau seseorang yang tampil dengan sudut pandang ini dianggap tidak berbahaya dan tidak penting bila difoto 
dari atas. Sudut pandang low angle, memberi efek kebalikan dari high angle, subjek yang difoto dengan sudut pandang ini sepertinya tampil heroik dan berkuasa atas pembaca. Sementara sudut pandang sejajar (eye level) memberikan indikasi subjek sejajar dengan pembaca. Keempat jenis sudut pandang ini menjadi basis bagi perkembangan sudut pandang yang lain extreme high angle dan extreme low angle.

Shot size: seberapa banyak tubuh subjek terekam dalam foto merupakan salah satu ukuran shot size. Shot size tidak berdasarkan jarak antara kamera dan objek pemotretan, karena lensa tertentu dapat memberikan distorsi terhadap jarak. Sebagai contoh lensa telephoto yang dapat menghasilkan gambar close-up padahal jarak antara kamera dengan subjek cukup jauh. Jenis shot size yang menjadi dasar dalam foto jurnalistik, antara lain: long shot, medium shot dan close-up. Long shot berguna untuk memperlihatkan tempat kejadian atau peristiwa yang berhubungan dengan antar elemen foto, merupakan pengambilan gambar yang lebih luas, dan menunjukkan hubungan antara manusia, objek dan tidakan dengan ruang fisik, sehingga menciptakan makna yang tertuang dalam foto long shot yang menghubungkan subjek dengan konteks, ruang lingkup, dan jarak publik (dikutip dari Pramudyanto, 2013:54). Medium shot berguna untuk memperlihatkan subjek dan objek terlibat dan orang yang melihat foto dengan jarak medium shot akan memiliki kecenderungan untuk merasa nyaman, karena seperti sebuah pengamatan yang normal (dikutip dari Pramudyanto, 2013:54). Sedangkan close-up memiliki tujuan untuk memperlihatkan kedekatan dan keintiman serta detail terhadap objek foto, karena menyajikan tampilan yang diperbesar dari manusia, objek, maupun tindakan, hal ini akan menghasilkan hal yang lebih spesifik.

Lensa: seorang pewarta foto dapat menggunakan berbagai lensa yang memiliki kegunaan yang berbeda-beda untuk membuat sebuah foto berita. Sebagai contoh, lensa tele-photo dapat digunakan untuk mendekatkan subjek yang di foto dari jarak jauh yang memiliki tujuan untuk menghasilkan efek tertentu seperti ruang tajam yang sempit, begitu pula dengan gambar-gambar yang datar akan mengurangi jarak diantara dua elemen foto, sehingga memungkinkan menghasilkan gambar yang lebih dekat ke subjek atau objek. Lensa lebar memiliki sudut pandang yang lebar, ruang yang tajam kedalam, dan distorsi ruang dan garis. Bila dua orang yang berdekatan difoto dengan menggunakan lensa ini, akan tampak berjauhan, membuat tampilan foto lebih dramatic, sedangkan lensa standar akan memberikan konotasi keseharian dan kenormalan, menghasilkan gambar yang imbang.

Pencahayaan: pencahayaan pada foto akan memberikan nuansa yang berbeda. Makna sebuah foto dengan pencahayaan yang terang (high key) akan menciptakan konotasi pada kebahagiaan. Sementara pencahayaan yang gelap (low key) akan memberikan konotasi pada hal kesedihan. Selain itu, foto dengan kontras tinggi tampak dramatis, sedangkan kontras rendah tampil lebih realistik.

Fokus: seorang fotografer dapat memainkan perannya dalam melakukan pengambilan foto dengan cara menggunakan salah satu dari dua jenis fokus. Pemilihan fokus dalam pengambilan sebuah foto tergantung pada fotografer yang ingin mengarahkan perhatian pembaca pada detail tertentu yaitu pada ruang yang tajam dan sempit (selective focus) atau ingin menampilkan keseluruhan elemen dalam foto (deep focus).

Penempatan subjek atau objek: setiap bidang foto mampu memberikan kesan dengan cara meletakkan subjek atau objek utama pada titik tertentu dan dapat di konotasikan sebagai seseorang yang memiliki karakteristik tertentu. Penempatan subjek atau objek di tengah bidang foto membuat subjek atau objek sebagai hal yang penting dalam suatu foto, lain halnya dengan penempatan suatu subjek atau objek di bagian atas bidang foto memberi kesan subjek atau objek itu mempunyai kekuatan, kontrol, dan otoritas. Sementara itu, penempatan subjek atau objek di pinggir bidang foto memberi kesan yang tidak penting, sedangkan penempatan subjek atau objek di bagian bawah bidang gambar memberikan kesan yang berlawanan dengan penempatan di bagian atas gambar.

\section{Maskulinitas}

Konsep maskulinitas yang dikembangkan dan diaplikasikan pada maskulinitas Connel (dikutip dari Speer, 2005:129) adalah maskulinitas hegemonik yang merupakan konfigurasi praktek gender, perwujudan suatu jawaban yang diterima saat ini dalam suatu masalah legitimasi patriarki, dimana posisi dominan laki-laki dan subordinasi perempuan, namun lain halnya dengan konsep maskulinitas yang dikembangkan oleh Wibowo (2011:131), dimana ia memberikan pendapat tentang maskulinitas yang merupakan suatu konsep yang hadir sebagai konstruksi sosial. Pendapat Wibowo senada dengan apa yang dikemukakan oleh Davies (dikutip dari Wibowo, 2011:131) yang mengatakan bahwa maskulinitas ataupun feminitas bukan milik pribadi tetapi tetapi merupakan properti struktural dari masyarakat tempat kita hidup, dua konsep tersebut dikondisikan dan timbul dari interaksi sosial. Intinya bahwa konsep maskulinitas dibentuk atau dengan sengaja dikonstruksi melalui berbagai bentuk interaksi yang melibatkan berbagai nilai yang berkembang di masyarakat.

\section{Pemaknaan Maskulinitas}

Konsep maskulinitas yang berlaku didalam suatu masyarakat tertentu, selalu berhubungan atau dikaitkan dengan dengan budaya, sejarah, geografis dan waktu, hak tersebut disampaikan oleh Beynon (2002:1) yang memiliki anggapan jika 'kelelakian' merupakan sesuatu biologis, maka maskulinitas 
merupakan hasil konstruksi kebudayaan. Menurutnya, pria tidak dilahirkan dengan maskulinitas melainkan mereka berakulturasi dengan kode-kode sosial dari perilaku yang mereka pelajari untuk mereproduksi dengan cara yang sesuai dengan budaya, sehingga maskulinitas dianggap sebagai wadah standar tentang sesuatu yang 'alami' yang dapat diukur dari segi sifatsifat psikologis dan atribut fisik.

Maskulin sebagai posisi laki-laki dalam fungsi relasi gender yang terkonstruksi secara sosial lebih dari sekedar perbedaan seksual atau biologi (Scott, 2011:153), hal tersebut juga ddidukung dengan pendapat Connel (dikutip dari Scott, 2011:153) menjelaskan studinya tentang gender dan power yang memiliki pengaruh tentang kekuatan superior lakilaki, sumber-sumber dan status merupakan sebuah fungsi dari perkembangan budaya dalam bentuk identitas gender, hegemoni maskulinitas, yang secara sosial membentuk dominasi mereka. Dominasi lakilaki di dunia publik kerja menurut pandangan Connel (dikutip dari Scott, 2011:153) mengarah pada studistudi mengenai maskulinitas dan manajemen, politik, ekonomi, lingkungan dengan beragam bentuk pergerakan laki-laki dan kebapakan, dimana secara sosiologis menemukan kembali "bapak yang hilang".

Identifikasi suatu pekerjaan yang paling konsisten untuk maskulin yang dapat dijumpai di seluruh dunia, menurut Murdock (dikutip dari Sanderson, 2011:395396) ialah kegiatan-kegiatan yang memerlukan kekuatan fisik yang lebih besar, tingkat resiko dan bahaya yang lebih tinggi, sering ke luar dari rumah, tingkat kerjasama kelompok yang lebih tinggi, masa latihan teknik yang lebih lama dan tingkat keterampilan yang lebih tinggi (Parker dikutip dari Sanderson, 2011:296).

\section{Konsep Gender}

Pandangan, anggapan dan gagasan tentang konsep gender yang selama ini terjadi pada kasus tertentu, memiliki cara pandang yang tumpang tindih karena beberapa masyarakat menganggap bahwa konsep gender yang berlaku dalam suatu masyarakat tertentu sama dengan kodrat jenis kelamin yang melekat kepada masing-masing individu yang tumbuh dan hidup dalam suatu masyarakat tertentu, padahal definisi konsep gender yang sebenarnya dikemukakan oleh Fakih (dikutip dari Aristiarini, 1998:4) yaitu konsep gender yang merupakan pelabelan jenis kelamin yang bisa dipertukarkan antara perempuan dan laki-laki, karena konsep gender sesungguhnya bukan kodrat, tetapi merupakan konstruksi sosial dimana laki-laki dan perempuan hidup. Ia berpendapat bahwa konsep gender merupakan hasil konstruksi tradisi, budaya, agama dan ideologi tertentu yang lahir atas kesepakatan nilai-nilai yang dianut masyarakat dan yang menentukan sesuatu hal yang lazim dilakukan oleh perempuan dan laki-laki, mengenal batas ruang dan waktu dan mampu membentuk karakteristik laki-laki maupun perempuan sehingga dapat berubah dalam situasi maupun kondisi tertentu.

Perbedaan pendapat-pendapat umum masyarakat tentang konsep gender dan jenis kelamin juga disampaikan oleh Samovar (2010:188), ia menyatakan bahwa identitas gender agak berbeda dengan identitas seks secara biologis, menurutnya gender merujuk pada bagaimana budaya tertentu membedakan peranan sosial feminin dan maskulin. Senada dengan Ting-Toomey (dikutip dari Samovar, 2010:188) yang mengemukakan identitas gender singkatnya merujuk pada pengertian dan interpretasi yang kita miliki yang berhubungan dengan gambaran pribadi dan gambaran lain yang diharapkan dari seorang laki-laki dan perempuan. Namun pada kenyataannya dalam suatu masyarakat tertentu menurut Fakih (dikutip dari Aristiarini, 1998:5), pada umumnya pemahaman tentang maskulin yang muncul masih disandangkan kepada laki-laki, yang kemudian dikonstruksikan sebagai pencari nafkah utama dalam keluarga, bergerak diruang publik dan produktif, namun disisi lain ada pemahaman feminin yang dilabelkan kepada perempuan, yang kemudian dikonstruksikan sebagai pencari nafkah tambahan dalam keluarga, bergerak diruang domestik dan memerankan reproduktif.

Disisi lain istilah gender menurut Oakley (dikutip dari Relawati, 2011:4) adalah perbedaan kebiasaan atau tingkah laku antara perempuan dan laki-laki yang dikonstruksikan secara sosial, yang dibuat oleh lakilaki dan perempuan itu sendiri, hal tersebut merupakan bagian dari kebudayaan. Pembedaan perempuan dan laki-laki menurut gender didasarkan pada budaya yang berdasar nilai-nilai dan normanorma yang berlaku di masyarakat, sehingga konstruksi gender bisa berbeda antara kelompok masyarakat satu dengan yang lain.

Perbedaan dalam hal pembagian peran dalam pekerjaan tertentu juga terjadi dimasyarakat, seperti yang diungkapkan oleh Relawati (2011:4) ia berpendapat bahwa dalam konstruksi gender dapat terjadi perbedaan antar kelompok masyarakat, dan sangat mungkin terjadi perubahan bila nilai-nilai dan norma yang dianut masyarakat berkembang atau berubah.

Perbedaan pemahaman antara seks dan gender dapat diklaskifikasikan berdasarkan karakteristiknya, Relawati (2011:5) antara lain melalui sumber pembeda, unsur, sifat, dampak dan keberlakuan. Sumber pembeda antara seks dan gender, jika seks berasal dari Tuhan sedangkan gender diberikan oleh manusia (masyarakat), unsur yang terdapat pada seks berupa aspek biologis (alat reproduksi) sedangkan pada gender dalam bentuk kebudayaan (tingkah laku), sifat seks kodrat tertentu, tidak dapat dipertukarkan sedangkan pada gender berupa harkat, martabat dan dapat dipertukarkan, dampak pada seks terciptanya nilai-nilai kesempurnaan, kenikmatan, kedamaian, sehingga menguntungkan kedua belah pihak sedangkan pada gender terciptanya norma tentang 
"pantas" atau "tidak pantas", keberlakuan pada seks sepanjang masa, dimana saja, tidak mengenal pembedaan kelas sedangkan pada gender dapat berubah, musiman dan berbeda antara kelas.

Dari penjelasan diatas, memberikan pemahaman kepada kita yang selama ini memiliki kesalahan pemahaman dalam membedakan antara jenis kelamin dan gender. Namun, satu faktor pembeda yang menjadi tambahan dalam memberikan perbedaan antara jenis kelamin dan gender menurut Samovar (2010:189), adalah faktor budaya yang juga turut berpengaruh untuk membentuk keindahan gender dan bagaimana hal itu ditampilkan di antara budaya dengan bahasa yang merupakan cara lain untuk menunjukkan perbedaan gender, sebagai contoh konkret seperti yang terjadi di Jepang, dimana katakata tertentu digunakan secara khusus oleh perempuan, sedangkan laki-laki menggunakan katakata yang berbeda untuk menyatakan arti yang sama.

\section{Konsep Budaya Patriarki}

Konsep patriarchy (patriarkat) digunakan untuk menggambarkan bentuk organisasi yang khusus, yakni rumah tangga, dimana ayah memiliki dominasi terhadap seluruh anggota keluarga lain dalam hubungannya dengan keluarga besar (extended family), serta mengontrol semua produksi ekonomi rumah tangga. Dengan demikian patriarkat menurut Billing dan Averson (dikutip dari Partini, 2013:14) merupakan pencerminan suatu hukum sang ayah, dan hukum tersebut berlaku terhadap individu lain yang berada di dalam suatu keluarga inti (nuclear family). Hal ini tidak terbatas pada pencerminan hukum didalam keluarga saja tetapi mencakup seluruh otoritas laki-laki sebagai ekspresi dari ayah secara simbolik.

Konsep patriarkat seperti yang diungkapkan oleh Mies (dikutip dari Partini 2013:14) mencakup dominasi pada tingkat sosial dimana biasanya lakilaki memegang posisi kekuasaan politik, sosial, ekonomi dan kehidupan kerja sementara perempuan tidak mempunyai akses untuk posisi tersebut.

Pada garis nalar yang sama dikemukakan oleh Tiger (dikutip dari Sanderson, 2011:409) yang berpendapat bahwa laki-laki dominan secara politis dalam semua masyarakat karena predisposisi biologis bawaan mereka, dan bahwa laki-laki secara alamiah cenderung membentuk ikatan-ikatan sosial yang erat antara yang satu dengan yang lainnya sebagai suatu strategi untuk mempertahankan diri kelompok.

Konsep patriarchy menurut Mileet (dikutip dari Partini, 2013:14) sebagai konsep kunci yang umum. Menurutnya, laki-laki dan perempuan dilukiskan sebagai makhluk yang berada di dalam hubungan dominasi-subordinasi. Lebih lanjut, Partini (2013:14) memiliki pendapat pada dasarnya penjelasan mengenai patriarchy diatas mencakup hierarki hubungan sosial dan institusi dimana laki-laki mempunyai kemampuan untuk mendominasi perempuan.
Pengertian mengenai konsep patriarki ini dikemukakan juga oleh Hartmann (dikutip dari Partini, 2013:15) yang menunjukkan bahwa dalam sistem patriarchy, laki-laki mengontrol kerja perempuan baik didalam rumah maupun di luar rumah. Didalam rumah, pekerjaan perempuan berlangsung rutin dan melelahkan, dan pekerjaan jenis ini dianggap bukan sebagai suatu pekerjaan sehingga perempuan tergantung pada suami. Diluar rumah, dapat dilihat antara lain bahwa laki-laki menyisihkan perempuan dari pekerjaan yang berupah tinggi.

Definisi tentang konsep patriarki yang merupakan sebagai sistem sosial hubungan gender yang didalamnya terdapat ketidaksetaraan gender, Walby (dikutip dari Scott, 2011:193) mengemukakan tentang relasi gender adalah relasi sosial antara laki-laki dengan perempuan dan melekat dalam berbagai institusi sosial dan struktur sosial. Konsep patriarki menggabungkan konsep hubungan-hubungan gender, dan kemudian berkembang menjadi dua pandangan. Pertama, meliputi ketidakadilan yang sering terjadi dalam relasi gender. Kedua, menarik perhatian kepada keterhubungan antara beberapa aspek hubungan-hubungan gender yang berbeda yang kemudian membentuk sistem sosial.

Dalam berbagai aspek kehidupan sosial terdapat ketidakadilan gender, dimana perempuan sering tidak diuntungkan jika dibanding dengan laki-laki. Lakilaki mengambil porsi yang berlebih dalam kekuasaan politik, misalnya menjadi anggota parlemen dan terlihat memiliki pengaruh untuk membentuk kultur dan standar moral. Beberapa definisi awal cenderung memfokuskan diri kepada peran laki-laki dewasa sebagai kepala rumah tangga, meliputi fokus kepada generasi dan satu lembaga sosial yang spesifik. Definisi yang paling akhir saat ini tampak lebih leluasa dimana lembaga-lembaga sosial dipandang berkontribusi dalam membentuk patriarki, dan keluarga menjadi salah satunya. Walby (dikutip dari Scott, 2011:193-194) memberikan penegasan bahwa patriarki hadir dalam interaksinya dengan sistem hubungan-hubungan sosial yang lain, seperti kapitalisme dan sistem hubungan-hubungan etnik. Interaksi tersebut telah mengubah karakter hubunganhubungan gender di dalam sistem patriarki. Khususnya, hal itu memisahkan pengalaman dan praktik perempuan dari kelas dan lokasi etnik yang berbeda.

Ada pendapat lain dari Relawati (2011:7) tentang banyaknya mitos lain yang lebih umum juga menjadi penyebab ketidakadilan gender, misalnya laki-laki selalu dianggap bertindak berdasarkan rasional, sedangkan kaum perempuan selalu mendahulukan perasaan. Kebanyakan mitos-mitos yang muncul di masyarakat akan menguntungkan kaum laki-laki dan mendiskreditkan kaum perempuan. Adanya mitosmitos tersebut disebabkan adanya budaya patriarki (budaya yang lebih mementingkan laki-laki), dalam keluarga yang berkuasa adalah bapak. Relawati (2011:7) menjelaskan bahwa patriarki 
menggambarkan dominasi laki-laki dalam semua lingkup kemasyarakatan lainnya. Patriarki adalah konsep bahwa laki-laki memegang kekuasaan atas semua peran penting dalam masyarakat, dalam pemerintahan, militer, pendidikan, industri, bisnis, perawatan kesehatan, iklan, agama dan lain sebagainya.

\section{Konsep dan Definisi Stereotype}

Strereotype merupakan bentuk kompleks dari pengelompokan yang secara mental mengatur pengalaman kita dan mengarahkan sikap kita dalam menghadapi orang-orang tertentu (Samovar, 2010:203). Hal ini menjadi cara untuk mengatur gambaran-gambaran yang kita miliki ke dalam suatu kategori yang pasti dan sederhana yang kita gunakan untuk mewakili sekelompok orang. Abbate (dikutip dari Samovar, 2010:203) memberikan pengertian yang lebih formal yaitu "Stereotype merupakan susunan kognitif yang mengandung pengetahuan, kepercayaan dan harapan si penerima mengenai kelompok sosial manusia". Alasan mengapa stereotype itu begitu mudah menyebar adalah karena manusia memiliki kebutuhan psikologis untuk mengelompokkan dan mengklasifikasikan suatu hal.

Stereotype dapat positif maupun negatif. Stereotype menurut Samovar (2010:203) yang merujuk sekelompok orang sebagai orang malas, kasar, jahat, atau bodoh jelas-jelas merupakan stereotype negatif. Bagaimanapun stereotype mempersempit persepsi kita, maka stereotype dapat mencemarkan komunikasi antar budaya. Hal ini karena stereotype cenderung untuk menyamaratakan ciri-ciri sekelompok orang.

\section{Budaya dan Stereotype Gender}

Anggapan tentang laki-laki mempunyai sifat-sifat tertentu yang berbeda dari perempuan. Laki-laki dianggap tidak emosional, mandiri, kuat, independen, dan sebagainya, sedangkan perempuan dianggap lemah, penuh kasih sayang, emosional, dependen dan sebagainya. Menurut Sarwono (2015:110) anggapan seperti itu adalah stereotype, yaitu dianggap berlaku untuk siapa saja hanya karena ia seorang laki-laki atau ia seorang perempuan, padahal cukup banyak laki-laki atau perempuan yang tidak seperti yang digambarkan oleh stereotype tersebut.

Sebuah penelitian pada tahun 1982 dan 1994 di 30 negara menemukan kesamaan lintas budaya yang sangat tinggi tentang sifat-sifat yang digunakan untuk menggambarkan laki-laki dan perempuan. Wiliiams dan Best (dikutip dari Sarwono, 2015:111) adalah yang melakukan penelitian tersebut, mereka mendapatkan temuan bahwa laki-laki selalu digambarkan bersifat lebih kuat dan lebih aktif. Lakilaki biasanya digambarkan sebagai aktif, kuat, kritis, dewasa, dengan kebutuhan untuk dominan, otonomi, agresi, pamer, prestasi dan mampu bertahan lama. Perempuan dipandang sebagai pasif, lemah, mengasuh, menyesuaikan dengan merendah, menghargai, mengasihi, afiliasi dan heteroseksualitas. Kesimpulan penelitian ini, peneliti-peneliti menduga bahwa temuan-temuan mereka mendukung adanya "psychological universal" yang terkait dengan stereotype gender.

Secara terperinci Williams \& Best (dikutip dari Sarwono, 2015:111-112) merumusukan tentang sifatsifat yang diasosiasikan pada laki-laki antara lain:

Laki-laki: acuh tak acuh, agresif, aktif, angkuh, arogan, autokratik, banyak akal, berani, bossy, cari kesenangan, dogmatis, gelisah, giat, humoris, individualistik, inisiatif, kacau, kaku, kejam, keras, keras (berisik), keras kepala, kuat, malas, mampu, mantap, minat yang luas, munafik, pamer, pandangan tajam, pasti, pelit, penemu, percaya diri, petualang, presisi, progresif, rasional, realistik, serius, sinis, tak banyak bicara, tak bermoral, tak bersahabat, tak menyenangkan, tangguh, sementara itu sifat yang diasosiasikan pada perempuan antara lain: baik hati, berhati-hati, berubah-ubah, bingungan, bodoh, canggih, emosional, gugup, hangat, hati lembut, imaginatif, ingin tahu, lemah, lembut, malu-malu, mengasihani diri sendiri, menghargai, menyenangkan, mudah dibisiki, mudah terangsang, mudah tersinggung, pemaaf, pemalu, pemimpi, penakut, pencemas, pengertian, penyayang, plin-plan, rewel, ringan, sabar, sederhana, seksi, sembrono, sensitif, sopan santun, submisif, suka komplain, tahayul, tak berambisi, tak stabil, tak terpelajar, tergantung, terpengaruh, tukang bicara, dan usikan.

\section{METODE PENELITIAN}

Agar penelitian ini mudah dipahami, maka peneliti menggunakan paradigma interpretif yang menekankan pada pengalaman subjektif seseorang dalam memahami suatu fenomena. Menurut West (2008:75), paradigma interpretif melihat kebenaran sebagai sesuatu yang subjektif dan diciptakan oleh partisipan atau peneliti, terdapat lebih sedikit penekanan pada objektivitas, serta tidak terlalu mementingkan kontrol dan kemampuan untuk melakukan generalisasi ke banyak orang, melainkan memberikan penjelasan yang kaya mengenai individu yang mereka teliti sehingga paradigma interpretif dapat digunakan sebagai basis untuk mendapatkan sebuah kesimpulan yang semakin lama semakin mendalam.

\begin{tabular}{|c|c|c|c|}
\hline $\begin{array}{l}\text { First order of } \\
\text { signification } \\
\text { (denotasi) }\end{array}$ & $\begin{array}{c}\text { Signifier } \\
\text { (penanda) }\end{array}$ & $\begin{array}{c}\text { Signified } \\
\text { (pertanda) }\end{array}$ & \\
\hline $\begin{array}{l}\text { Second order of } \\
\text { signification } \\
\quad \text { (konotasi) }\end{array}$ & \multicolumn{2}{|c|}{$\begin{array}{c}\text { SIGN } \\
\text { Signifier } \\
\text { (penanda konotatif) }\end{array}$} & $\begin{array}{l}\text { Signified } \\
\text { (pertanda } \\
\text { konotatif) } \\
\end{array}$ \\
\hline $\begin{array}{l}\text { Third order of } \\
\text { signification } \\
\text { (mitos/ideologi) }\end{array}$ & \multicolumn{2}{|c|}{ SIGN } & \\
\hline
\end{tabular}

Sedangkan untuk metode penelitian pada penelitian ini menggunakan analisis isi-kualitatif yang berusaha mengkonstruksi realitas dan memahami 
maknanya, memperhatikan proses, peristiwa dan otentitas sesuai dengan hal-hal tematik yang ingin dianalisis (Somantri, 2005:58). Melalui metode analisis isi fenomena dapat digambarkan secara detail dari suatu pesan atau teks tertentu, semakin lengkap peneliti dalam mengungkapkan karakteristik dari pesan atau teks tersebut, kualitas penelitian akan semakin baik (Eriyanto, 2011:47).

Untuk menggambarkan secara detail mengenai suatu pesan atau suatu teks media, pada penelitian ini akan menggunakan metode analisis isi semiotika model Roland Barthes yang memiliki fungsi untuk menggambarkan suatu pesan-pesan tersembunyi dalam sebuah simbol, lambang, gambar atau tampilan visual.

Barthes (dikutip dari Wibowo, 2011:16) memberikan pendapat tentang denotasi yang berfungsi sebagai primary sign system dan merupakan makna paling nyata dari sebuah tanda (sign), sementara itu konsep lain yang terdapat dalam semiotika model Barthes adalah konotasi sebagai secondary sign system yang menjadi kunci penting, karena konotasi memiliki makna yang subjektif dan dapat menunjukkan perasaan emosi dari pembaca serta nilai-nilai kebudayaannya, dan elemen terakhir untuk menggambarkan suatu pesan-pesan tersembunyi dalam sebuah simbol, lambang, gambar atau tampilan visual dengan menggunakan model semiotika Barthes (dikutip dari Sobur, 2004:71) adalah dengan menggunakan mitos yang berfungsi untuk mengungkapkan dan memberikan pembenaran bagi nilai-nilai dominan yang berlaku dalam suatu periode tertentu. Mitos dibangun oleh suatu rantai pemaknaan yang telah ada sebelumnya atau dengan kata lain mitos adalah juga suatu sistem pemaknaan tataran kedua. Didalam elemen mitos, Barthes memampatkan ideologi sebagai kesadaran palsu yang membuat orang hidup didalam dunia yang imajiner dan ideal, meski realitas hidupnya yang sesungguhnya tidaklah demikian, menurut Barthes ideologi mewujudkan dirinya melalui kode yang masuk ke dalam teks berupa penanda-penanda penting, seperti tokoh, latar, sudut pandang, dan lain-lain.

Mengacu kepada bagan pemetaan semiotika yang dikembangkan oleh Roland Barthes berikut ini yang akan digunakan sebagai "pisau analisis" untuk mengungkap makna-makna denotatif, konotatif dan mitos yang terkandung dalam tampilan visual fotofoto jurnalistik kandidat presiden RI tahun 2014 yang dimuat di tiga surat kabar harian nasional.

Sementara itu pada rencana analisis data penelitian, secara garis besar akan dilakukan tiga langkah dalam proses analisis data penelitian melalui tahapan seperti yang diarahkan oleh Miles dan Huberman (2014:16-21). Pertama, reduksi data yaitu proses pemilihan data foto-foto jurnalistik yang menampilkan sosok kandidat presiden tahun 2014 yang terbit dalam harian surat kabar nasional periode Mei 2014 sampai dengan Juli 2014. Kedua, penyajian data yaitu menyajikan dan menganalisis data dengan menggunakan model semiotika Roland Barthes dengan tiga elemen yang terdiri dari denotatif, konotatif dan mitos pada tampilan visual foto-foto jurnalistik yang dimuat di tiga surat kabar harian nasional. Ketiga, menarik kesimpulan dan verifikasi yaitu melakukan verifikasi melalui wawancara dengan narasumber yang memiliki kompetensi atau yang terlibat didalam data penelitian seperti fotografer jurnalistik dan psikolog sosial.

\section{PEMBAHASAN}

Data mentah yang didapatkan oleh peneliti yang nantinya akan dianalisa dengan menggunakan metode semiotika model Roland Barthes, didapatkan dari kumpulan data yang sudah direduksi sedemikan rupa sehingga didapatkan data berdasarkan atas kriteria atau pertimbangan tertentu. Fokus pada penelitian ini, maka data penelitian dikelompokkan berdasarkan tampilan visual sosok kandidat presiden RI tahun 2014 melalui foto-foto jurnalistik yang dimuat di surat kabar harian nasional yang mempelihatkan aktivitas dan peran kandidat presiden dalam satu liputan.

Dengan mengacu pada penjelasan diatas, maka peneliti menetapkan 26 foto-foto jurnalistik yang dimuat di tiga surat kabar harian nasional yang terbit pada periode Mei 2014 sampai dengan Juli 2014. 26 foto-foto jurnalistik tersebut terdiri dari 11 foto jurnalistik yang dimuat di surat kabar harian Kompas, 6 foto jurnalistik yang dimuat di surat kabar harian Seputar Indonesia dan 9 foto jurnalistik yang dimuat di surat kabar harian Media Indonesia.

Setelah proses analisa foto-foto jurnalistik, maka peneliti berhasil mendapatan kategorisasi yang erat kaitannya dengan sifat-sifat maskulinitas yang dihubungkan dengan konsep gender, budaya patriarki dan sterotype yang melekat pada kandidat presiden RI dalam pemilihan umum presiden tahun 2014. Kategorisasi yang didapatkan adalah berdasarkan gabungan kriteria atau sifat yang paling dominan mucul diantara kedua kandidat presiden RI Prabowo Subianto dan kandidat presiden RI Joko Widodo. Kategorisasi tersebut antara lain:

Religius: kategori religius yang tampak dan menjadi kategori utama dalam pembahasan hasil penelitian ini, dengan satu alasan tertentu yaitu sosok laki-laki yang hidup, tumbuh dan berkembang secara fisik dan psikologis dalam lingkungan sosial yang dikaitkan dengan konsep gender, budaya patriarki dan stereotype, dianggap sebagai sosok imam dalam keluarga, yang memiliki fungsi sebagai pilar utama dalam rumah tangga, bertugas memimpin seluruh elemen yang terdapat didalamnya, sama halnya dengan tugas yang diberikan kepada sosok laki-laki yang memiliki tugas dan tanggung jawab dengan ruang lingkup yang lebih besar bahkan terbesar yakni sebagai seorang pemimpin negara, sehingga dengan dasar itu maka seorang laki-laki cenderung dituntut untuk memiliki sifat religius dan dianggap sebagai suatu kewajiban dalam membentengi dirinya sendiri sesuai dengan kepercayaan dan iman yang ia anut. 
Sifat dan peran religius dapat dilekatkan kepada sosok pria yang maskulin terdapat kemungkinan bahwa gambaran Tuhan dari kepercayaan dan agama di percaya sebagai sosok laki-laki, jika dalam agama Islam yang berperan sebagai Tuhan adalah Nabi Muhammad SAW, sementara di agama kristiani yang berperan sebagai Tuhan adalah Yesus Kristus. Dengan demikian, sosok laki-laki diberikan atribut untuk melakukan tindakan, sifat-sifat dan peran seperti Tuhan yang mengajarkan hal-hal yang baik, dan melakukan hal yang dilakukanNya kepada umatNya.

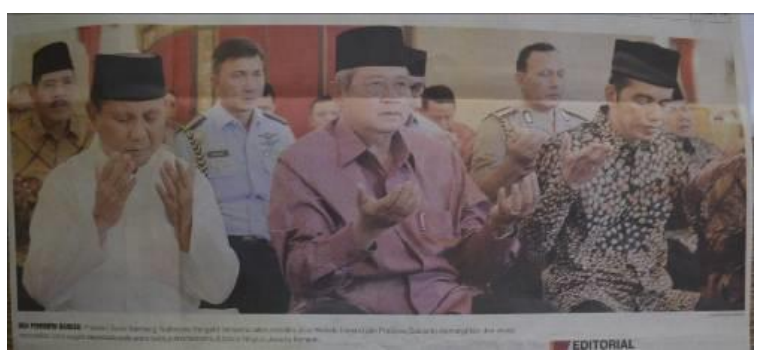

Gambar 1. Religius

Tegas: kategori tegas menjadi kategori kedua dalam pembahasan atas hasil temuan dalam hasil penelitian, dengan alasan tertentu yakni sosok laki-laki yang hidup, tumbuh dan berkembang secara fisik dan psikologis dalam lingkungan sosial yang dikaitkan dengan konsep gender, budaya patriarki dan stereotype, sosok laki-laki tersebut dianggap sebagai sosok yang memiliki pengaruh yang kuat baik dalam keluarga maupun dalam lingkungan masyarakat sosial, sehingga hal itu menjadi suatu kebiasaan yang berlaku dalam masyarakat patriarkat, jika dalam menentukan sesuatu hal, menentukan sikap tertentu, sampai menentukan pilihan apapun segala sesuatunya diserahkan kepada sosok laki-laki yang cenderung dianggap memiliki sifat yang tegas atau mampu menjelaskan segala sesuatu yang cenderung benar dan tidak adanya keragu-raguan dalam menyampaikannya. Pernyataan tersebut mengindikasikan bahwa sosok laki-laki dalam menjalankan peranya di asosiasikan sebagai sosok yang tegas, karena ia mampu menempatkan diri apabila ada hal-hal yang sesuai dengan logika dan cara berpikir yang sesuai dengan pikirannya maka sosok laki-laki memiliki kemampuan untuk menetapkan sikap ya berkata ya dan tidak berkata tidak.

Impresif: kategori impresif menjadi kategori ketiga dalam sub-bab pembahasan atas hasil temuan dalam hasil penelitian, dengan alasan tertentu yakni sosok laki-laki yang dihidup, tumbuh dan berkembang secara fisik dan psikologis dalam lingkungan sosial yang dikaitkan dengan konsep gender, budaya patriarki dan stereotype, sosok laki-laki tersebut sering dianggap mampu berperan sebagai garda depan dalam suatu komunitas sosial dimanapun ia ditempatkan sehingga dalam interaksi komunikasi dengan orang lain sosok pria membutuhkan waktu untuk melakukan penyelidikan diawal percakapan, maupun ketika melakukan percakapan atau interaksi dengan seseorang yang sudah dikenal sebelumnya berupa penglihatan dengan kedua mata yang bersifat tetap dan dalam jangka waktu yang lama sehingga menumbuhkan kesan atau impresi yang dalam terhadap pikiran atau perasaan lawan bicaranya, yang pada akhirnya dapat mempengaruhi sikap dan tindakan yang dikehendaki oleh sosok laki-laki tersebut. Sama halnya dengan yang dilakukan oleh sosok kandidat presiden RI yang dengan sikap tatapan tajam yang diarahkan kepada masing-masing lawan bicaranya dengan tujuan untuk melakukan penyelidikan tertentu, dan apabila ada hal-hal yang tidak sesuai, ia dapat melindungi dirinya dari jawaban, reaksi yang ditemukan dari lawan bicaranya.

Gambar 2. Ketegasan

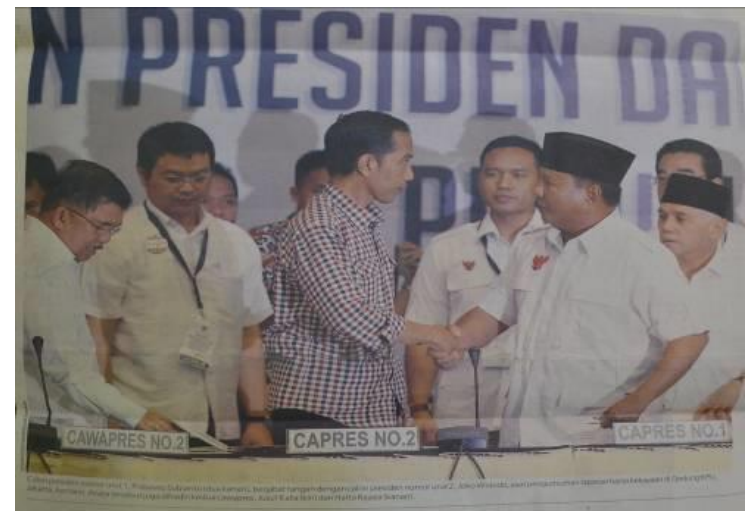

\section{Temuan Lain}

Berdasarkan hasil temuan penelitian yang dilakukan terdapat beberapa sifat yang hanya melekat pada diri kandidat presiden RI tahun 2014 dari salah satu kandidat saja. Jika, ditelusuri lebih lanjut maka sifat yang melekat pada diri kandidat presiden RI Prabowo Subianto antara lain:

Sombong: elemen sombong menjadi sifat yang cenderung melekat pada kandidat presiden RI Prabowo Subianto, karena dengan alasan tertentu yakni sosok laki-laki yang dihidup, tumbuh dan berkembang secara fisik dan psikologis dalam interaksi dengan lingkungan budaya patriarki, lakilaki sering dianggap 'motor' dalam memberikan penghasilan bagi keluarga dan menjadi tulang punggung keluarga, maka sebagai bentuk kompensasinya ia merasa bangga dan hebat atas hasil pekerjaan yang ia geluti dan atas pencapaian atau prestasi yang dapat ia raih maka seorang laki-laki cenderung menunjukkan atau mendemonstrasikan baik kekayaan atau kehebatan yang dimiliki kepada orang lain dengan maksud memperlihatkan kelebihan atau keunggulan tersebut untuk menyombongkan diri. Ambisius: elemen ambisius menjadi sifat yang cenderung melekat pada kandidat presiden RI Prabowo Subianto, karena dengan alasan tertentu. Ia sebagai sosok laki-laki yang dihidup, tumbuh dan berkembang secara fisik dan psikologis dalam interaksinya dengan lingkungan sosialnya, dituntut dan dibentuk, apabila dalam menentukan segala 
sesuatu harus dilakukan dengan sungguh-sungguh sesuai dengan kata hati agar keinginannya, hasrat, nafsu yang besar untuk memperoleh dan mencapai sesuatu yang ia inginkan kelak dapat terpenuhi.

Seseorang yang memainkan perannya dalam kehidupan sehari-sehari sebagai sosok yang ambisus terkadang dinilai baik atau buruknya dari dua kacamata yang berbeda, tergantung bagaimana orang lain memberikan penilaian kepadanya. Baik buruk sikap seseorang terhadap peran ambisius dapat dinilai dari sudut pandang yang negatif atau positif.

Gambaran peran ambisius yang bersifat negatif, umumnya digambarkan sebagai seseorang yang menggebu-gebu dalam menginginkan sesuatu yang menjadi keinginannya, umumnya dalam mengejar keinginannya, hasrat dan nafsunya seseorang terkadang lupa dengan situasi dan kondisi yang ada dilingkungan sosialnya bahwa ada hal-hal lain yang membutuhkan perhatian, tidak hanya sekedar perannya untuk menggapai harapan dan cita-cita yang diinginkan. Umumnya, jika suatu situasi dan kondisi tersebut sudah terjadi, hal-hal yang diinginkan atau dicita-citakan tidak akan tercapai, begitu pula hal-hal yang perlu mendapatkan perhatian tidak terpenuhi.

Sementara itu, gambaran positif yang dapat digambarkan melalui peran yang ambisius berupa sikap dan tingkah laku yang fokus dalam menggapai harapan dan cita-cita tertentu, dan digambarkan dalam bentuk usaha, kerja keras, dan menghargai proses demi prosesnya.

Jika kandidat presiden RI Prabowo Subianto memiliki sifat yang melekat sebagai pribadi yang memiliki kecenderungan sifat dan berperan sebagai sosok yang sombong, dan ambisius, maka lain halnya dengan sifat yang melekat pada diri sosok kandidat presiden RI Joko Widodo, yang jika ditelusuri lebih lanjut ia tampak memiliki sifat yang tergambar dibawah ini:

Pembelajar: elemen pembelajar menjadi salah satu elemen atas sifat-sifat yang melekat pada kandidat presiden RI Joko Widodo, karena dengan alasan tertentu yakni dalam interaksinya dengan lingkungan sosialnya ia sering dianggap sebagai seseorang yang lebih memiliki motivasi atau dorongan dari dalam diri sendiri untuk belajar tentang suatu hal baru, sehingga ilmu yang ia pelajari dianggap sebagai investasi yang berharga dalam menghadapi tantangan yang berasal dari lingkungan sekitarnya dengan tujuan agar tidak mudah dipengaruhi oleh keadaan tertentu, dan hanya sosok laki-laki yang umumnya memiliki sikap untuk memilih aktivitas atau pekerjaan yang memberikan kesenangan dan kepuasan bagi dirinya. Jika ditelusuri lebih dalam mengenai perannya sebagai sosok yang pembelajar, ia dianggap sebagai sosok yang lebih kaya dari sisi ilmu pengetahuan, karena dengan sikapnya yang mau belajar hal-hal baru pada akhirnya memiliki manfaat untuk proses pengembangan dirinya dan memiliki manfaat bagi lingkungan sosialnya. Tentu saja hal ini dianggap sebagai suatu kelebihan, dengan sifat ilmu pengetahuan yang menetap dalam diri kita sampai akhir hayat akan menjadi bekal bagi diri kita.

Seorang pembelajar yang divisualisasikan di media massa, akan memiliki peluang dalam memberikan penilaian terhadap persepsi khalayak. Umumnya, penilaian yang diberikan kepada sosok pembelajar dinilai sebagai sosok yang pintar, pandai, dan dianggap menguasai semua bidang ilmu pengetahuan. Motif media massa dalam mengangkat sosok pembelajar dengan tujuan tertentu agar khalayak memiliki sikap simpati, dan hormat terhadap seseorang yang menguasai suatu bidang ilmu pengetahuan tertentu.

Mampu Bertindak: elemen mampu bertindak menjadi sifat yang cenderung melekat pada kandidat presiden RI Joko Widodo, karena dengan alasan tertentu. Ia dianggap sebagai sosok laki-laki yang dianggap lazim diberikan tugas dan tanggung jawab yang besar dengan penuh resiko dan tantangan yang tinggi, karena hanya sosok laki-laki lah yang mampu menyelesaikan dengan melakukan tindakan beresiko tersebut.

Kemampuan seseorang dalam mengambil suatu tindakan beresiko, umumnya dianggap sebagai suatu kelebihan karena tindakan yang diambil akan memberikan dampak terhadap perubahan menuju kearah yang lebih baik. Tindakan-tindakan yang dilakukan dapat berupa tindakan memperbaiki, merubah situasi dan kondisi, menjadi mediator dalam suatu permasalahan besar, sampai pada tindakan membangun atau menata kembali tatanan, pola, aturan yang berlaku dilingkungan sosial tertentu.

Sikap dan peran seseorang dalam memperbaiki, merubah situasi dan kondisi, menjadi mediator dalam suatu permasalahan besar, sampai membangun atau menata kembali pola, aturan yang berlaku dalam lingkungan sosial dapat dilihat dalam bentuk visual di media massa yang bertujuan untuk membangun imajinasi khalayak yang menyaksikan atau membacanya. Dalam menampilkan sosok laki-laki yang mampu bertindak di media massa, tentunya terdapat motif yang ingin di sampaikan kepada khalayak. Misalnya, agar khalayak semakin yakin menetapkan pilihan hatinya untuk memberikan suara kepada salah satu kandidat yang ada dalam pertarungan politik tertentu, karena citra yang disampaikan di media massa sesuai dengan yang diharapkan, yaitu sebagai sosok yang mampu bertindak untuk melakukan perubahan.

\section{KESIMPULAN}

Kesimpulan yang dapat ditarik pada penelitian ini adalah setiap kandidat presiden RI tahun 2014 baik Prabowo Subianto maupun Joko Widodo keduanya merupakan sosok laki-laki yang hidup, tumbuh dan berkembang yang memilki sifat yang cenderung dominan antara lain sifat religus, tegas dan dalam setiap berinteraksi dan berkomunikasi dengan sesama 
individu yang berada dalam ruang lingkup sosial yang sama, keduanya tampak memiliki sifat dan tingkah laku untuk menatap mata lawan bicaranya yang mampu meninggalkan kesan yang mendalam atau impresif. Tetapi disisi lain, ada beberapa sifat yang terdapat dalam diri mereka masing-masing yang menjadi ke-khas-an dan menjadi suatu identitas atau karakteristik pribadi masing-masing. Ke-khas-an sifat atau karakteristik mereka tampak melekat bukan berasal dari sifat yang mereka bawa sejak lahir, melainkan sifat atau karakteristik mereka timbul atas hasil peran sosial yang dikaitkan dengan konsep gender, budaya patriarki dan stereotype yang dilekatkan kepada mereka.

Sifat-sifat khas yang dimiliki oleh kandidat presiden RI tahun 2014 Prabowo Subianto setelah didapatkan temuan dari hasil analisis data pada fotofoto jurnalistik yang dimuat di surat kabar harian Kompas, Seputar Indonesia dan Media Indonesia yang terbit pada periode Mei 2014 sampai dengan Juli 2014 adalah sifat akan kecenderungan sifat kesombongan dan kehebatannya dan kesungguhan hati yang ia miliki untuk meraih sesuatu yang ia harapkan. Sementara itu, sifat-sifat khas yang dimiliki oleh kandidat presiden RI tahun 2014 Joko Widodo setelah didapatkan temuan dari hasil analisis data pada foto-foto jurnalistik yang dimuat disurat kabar harian nasional dan periode yang sama maka didapatkan kesimpulan sosok Joko Widodo memiliki kecenderungan terhadap keinginan akan menambah ragam ilmu pengetahuan yang lain, selain ilmu pengetahuan dalam bidang politik dan pemerintahan yang selama ini ia geluti, atau dengan kata lain ia dapat dikatakan sebagai sosok yang pembelajar dan sifat akan kepercayaan yang diberikan kepadanya untuk melakukan sesuatu hal dalam memecahkan suatu konflik atau problematika sosial yang terjadi melalui tindakan yang dipercayakan kepadanya.

\section{REFERENSI}

Abdullah, Irwan. (2003). Penelitian Berwawasan Gender Dalam Ilmu Sosial. Jurnal Humaniora, Fakultas Ilmu Budaya Universitas Gadjah Mada, 15 (2), 266.

Aristiarini, Agnes. (1998). Menggagas Jurnalisme Sensitif Gender. Yogyakarta: PMII Komisariat IAIN Sunan Kalijaga

Beynon, John. (2002). Masculinities and Culture. UK: Open University Press.

Darwin, Muhadjir. (1999). Maskulinitas: Posisi Laki-laki dalam Masyarakat Patriarkis. Centre for Population and Policy Studies Gadjah Mada University, 3.

Eriyanto. (2011). Analisis Isi: Pengantar Metodologi Untuk Penelitian Ilmu Komunikasi dan Ilmu-ilmu Sosial Lainnya. Jakarta: Kencana

Irsyad, R. (2005). Representasi Tentara Amerika Serikat Dalam Foto Berita Di Surat Kabar Nasional (Analisis Semiotika Foto Berita Tentang Tentara Amerika Serikat Selama 21 Hari Pertama Perang Irak Di Halaman Satu Surat Kabar Republika). (Thesis Magister Ilmu Komunikasi, Fakultas Ilmu
Sosial dan Ilmu Politik, Universitas Indonesia, 2005)

Lampe, Ilyas. (2014). Perempuan Dalam Pengelolaan Surat Kabar di Sulawesi Tengah (Studi Posisi dan Peran Perempuan dalam Media Cetak. Diakses pada 2 November 2016, dari http://jurnal.untad.ac.id/jurnal/index.php/academic a/article/view/2322/1509

Miles, M. B \& Huberman, A. M. (2014). Analisis Data Kualitatif: Buku Sumber Tentang Metode-Metode Baru. Jakarta: Universitas Indonesia (UI) Press

Muhtadi, Asep S. (1999). Jurnalistik Pendekatan Teori dan Praktik. Jakarta: Logos Wacana Ilmu

Nasdian, Fredian. T. (2015). Sosiologi Umum. Jakarta: Yayasan Pustaka Obor Indonesia

Nimrah, Siti. Sakaria. (2015). Perempuan dan Budaya Patriarki Dalam Politik (Studi Kasus Kegagalan Caleg Perempuan Dalam Pemilu Legislative 2014). Jurnal The Politics: Magister Ilmu Politik Universitas Hasanuddin (1) 2, 175.

Partini. (2013). Bias Gender Dalam Demokrasi. Yogyakarta: Tiara Wacana.

Pramudyanto, A. B. (2013). Representasi Repressive State Aparatus Dalam Foto Jurnalistik Media Massa (Analisis Semiotika Foto Jurnalistik Terkait Kasus Korupsi Simulator SIM di Surat Kabar Harian Kompas) (Thesis Magister Ilmu Komunikasi, Fakultas Ilmu Sosial dan Ilmu Politik, Universitas Indonesia, 2013

Relawati, Rahayu. (2011). Konsep dan Aplikasi Penelitian Gender. Bandung: Muara Indah.

Rivers, William. L, Jensen, Jan. W, Peterson \& Theodore. (2004). Media Massa dan Masyarakat Modern (terjemahan). Jakarta: Kencana.

Rokhmansyah, Alfian. (2016). Pengantar Gender dan Feminisme: Pemahaman Awal Kritik Sastra Feminisme. Yogyakarta: Garudhawaca

Samovar, Larry A. Porter, Richard E \& McDaniel, Edwin R. (2010). Communication Between Culture $7^{\text {th }}$ Edition (terjemahan). Jakarta: Salemba Humanika .

Sanderson, Stephen K. (2011). Makrososiologi: Sebuah Pendekatan Terhadap Realitas Sosiologi (terjemahan). Jakarta: Rajawali Pers.

Sarwono, Sarlito W. (2015). Psikologi Lintas Budaya. Jakarta: Raja Grafindo Persada.

Scott, John. (2011). Sosiologi: The Key Concept. Jakarta: Rajawali Pers.

Sobur, Alex. (2004). Semiotika Komunikasi. Bandung: Remaja Rosdakarya.

Somantri, Gumilar Rusliwa. (2005). Memahami Metode Kualitatif. Jurnal Makara Sosial Humaniora Fakultas Ilmu Sosial dan Ilmu Politik Universitas Indonesia 9 No. (2), 58.

Speer, Susan A. (2005). Gender Talk: Feminism, Discourse and Conversation Analysis. London: Routledge.

Sugiarto, Atok. 2005. Paparazzi: Memahami Fotografi Kewartawanan. Jakarta: Gramedia Pustaka Utama.

West, Richard \& Turner, Lynn H. (2008). Pengantar Teori Komunikasi Edisi 3: Analisis dan Aplikasi Buku 1 (terjemahan). Jakarta: Salemba Humanika .

Wibowo, Indiwan S.W. (2011). Semiotika Komunikasi: Aplikasi Praktis Bagi Penelitian dan Skripsi Komunikasi. Jakarta: Mitra Wacana Media. 